\title{
Impact of Capital Flow on Economic Growth in Ethiopia: Empirical evidence from (1980-2010) using ARDL Approach
}

Bewket Aschale Gashu ( $\sim$ bewketaschale77@gmail.com )

Wachemo University https://orcid.org/0000-0002-2383-9082

\section{Research Article}

Keywords: economic growth, capital flow, ARDL approach, Granger causality, Ethiopia

Posted Date: April 5th, 2021

DOl: https://doi.org/10.21203/rs.3.rs-393202/v1

License: (1) (1) This work is licensed under a Creative Commons Attribution 4.0 International License.

Read Full License 


\title{
Title page
}

\section{Impact of Capital Flow on Economic Growth in Ethiopia: Empirical evidence from (1980-2010) using ARDL Approach}

\author{
Bewket Aschale Gashu ${ }^{a^{*}}$ \\ Department of Economics, College of Business and Economics, Wachemo University, \\ Po.Box.667, Hossana, Ehiopia; bewketaschale77@gmail.com
}

\begin{abstract}
Author's Contribution and Bibliography
The sole author designed, analysed, interpreted and prepared the manuscript. The author is a senior lecturer in Wachemo University in the department of Mathematics, and currently he is a $\mathrm{PhD}$ candidate in the department of Science and Mathematics Education in Addis Ababa University, Ethiopia. Additionally, he is junior Economist and young researcher in the thematic areas of both education quality and (macro) economic development.
\end{abstract}

Corresponding author:

Bewket Aschale Gashu ${ }^{a^{*}}$

Department of Economics, College of Business and Economics, Wachemo University, Po.Box.: 667, Hossana, Ehiopia;

Email: bewketaschale77@gmail.com 


\section{Impact of Capital Flow on Economic Growth in Ethiopia: Empirical evidence from (1980-2010) using ARDL Approach}

\section{Bewket Aschale Gashu ${ }^{a^{*}}$}

Department of Economics, College of Business and Economics, Wachemo University, Po.Box. 667, Hossana, Ehiopia; bewketaschale77@gmail.com

\section{Author's Contribution and Bibliography}

The sole author designed, analysed, interpreted and prepared the manuscript. The author is a senior lecturer in Wachemo University in the department of Mathematics, and currently he is a $\mathrm{PhD}$ candidate in the department of Science and Mathematics Education in Addis Ababa University, Ethiopia. Additionally, he is junior Economist and young researcher in the thematic areas of both education quality and (macro) economic development.

March, 2021 


\title{
Impact of Capital Flow on Economic Growth in Ethiopia: Empirical Evidence from (1980 - 2010) using ARDL Approach
}

\begin{abstract}
Evidence abound that some transitioning and developing countries are attracting large inflows of foreign capital that could engender economic growth or have destabilizing effects on their economies if not well managed. This has undoubtedly aroused anxiety over its potential effects on economic growth, the competitiveness of the export and external sectors viability. The study examines the impact of capital flow on economic growth in Ethiopia as well as the causal short-run and long-run relationship among the variables, using time series data from 1980 - 2010. Using the ARDL Approach, the result revealed that all the variables are statistically significant; which implies that the capital flow has an impact on economic growth in both short- and long-run dynamic equilibrium models. Additionally, VAR and Innovative Accounting Techniques approach to Granger causality analysis showed that there exists bidirectional causality between gross capital flow and economic growth. Consequently, these findings suggest that policy makers should critically understand, the nature, what drives the capital flows and the impact of its sudden surge or reversal on economy. Moreover, it is also recommended that government should continue to pursue trade and foreign exchange policies that would ensure competitiveness of the export sector viability and economic growth.
\end{abstract}

Keywords: economic growth; capital flow; ARDL approach; Granger causality; Ethiopia. 


\section{Introduction}

The issue of foreign capital flows to Africa as a whole has become an important topics today among academic scholars. Since global economies were severely affected from the debt crisis in 1980s till present especially Africa, Latin America and few countries in Eastern Europe and Asia (Musibau et.al, 2017). Furthermore, Musibau argues that the Africa region had been seriously affected by currency fluctuations, decay infrastructural development, high level of corruption and economic and political instability among others banes which discourage foreign investors in most of African economies. However, the various form of inflow of foreign capital (loans, FDI, grant and portfolio) was welcome in developing countries to bridge the gap between domestic saving and domestic investment and therefore, to accelerate growth (Chenery et.al, 1996, cited in Wondwesen, 2011).

Generally, the most important permanent feature of the Ethiopian economy is the presence of resource (financial) gaps; these emanate from imbalances between exports and imports, between debt payments and resource inflows and between domestic savings and domestic investments (Anyanwu, 2012; cited in Musibau et.al, 2017). Consequently, the lack of adequate finance has reduced the ability of governments to embark on public expenditure in infrastructure and social services required to boost domestic demand, encourage private sector activity and sustain high level of growth for economic transformation (Onyeiwu, 2015, cited in Musibau, et.al, 2017). Hence, Girma, et.al, (2005, cited in Tasew, 2011) suggest that poor countries (including Ethiopia) provide aid from foreign advanced countries to finance investment can directly fill this saving-investment gap; and, aid can also indirectly fill the foreign exchange gap in the form of hard currency. Thus, this makes the importance of foreign capital inflow unquestionable to the performance of the economy (Wondwesen, 2011). 
Empirical findings about the impact of capital flow on economic growth are rare; it is almost negligible, especially in Ethiopia. Most papers at the country level, Ethiopia are focused on the effect of foreign capital inflow on economic growth; the impact of foreign aid on economic growth; the effect of foreign direct investment on economic growth; the causality of saving, investment and economic growth; and other. This study therefore, would be investigated how capital flow which includes both foreign capital inflow and domestic capital outflow affect the economic growth in Ethiopia. Furthermore, it would be encompassed, implicitly the effect of capital flow/foreign capital inflow and domestic capital outflow/ on gross domestic saving and gross domestic investment; and hence on economic growth. Hence, this study would fill gaps on studies which are limited only on one side flow of capital, foreign capital inflow effect on the economic growth of Ethiopia, by considering the two sides of capital flows, inflow and outflow effects. The main objective of this study is, therefore, to explore the macroeconomic impact of capital flow on economic growth in Ethiopia using data from 1980-2010. Moreover specifically, the paper tries to analyze the magnitude and direction of impact of capital flow on (domestic) saving and economic growth in both short run and long run; and also to examine the causal relationship between capital flow and economic growth in Ethiopia.

\section{Literature Review}

\section{Capital Flow and Economic Growth: Controversy Issue}

International capital flows not only offer a great deal of benefits to financially integrated countries, they also pose numerous macroeconomic challenges (Reinhart and Reinhart, 2008; Furceri et.al. 2011; as cited in Alley, 2017). According to Bailliu (2000, cited in Alley , 2017) on examination of the role of capital flows on economic growth using data on 40 developing countries, finds that the impact of capital flows on the economy depends on the level of financial market development: capital inflows have positive (negative) effect on growth when the country is financially developed (underdeveloped). 
Most scholars support the positive impact of foreign capital on economic growth. For example, Aizenman et al. (2013, cited in Musibau et.al, 2017) find a strong, robust relationship between FDI (both inflows and outflows) and growth. That is, Chen and Quang (2014) confirmed that the growth effect of international capital flows is contingent on the levels of economic, institutional and financial development and government spending (ibid). Moreover, moving capital flows from developed to developing countries would create employment opportunities and promote economic growth (Siddiqui, 2014, cited in Admasu, 2017). In contrary however, Adam (2009, cited in Musibau, 2017) argues that FDI has negative impact on Domestic Investment in the short run but positive effect in long run in the Sub-Sahara African economies and a net crowding out effect.

Generally for making negotiation these two views of controversial issues; capital flows in the global market should be focused in the analyses of the effects of investment and savings on economic growth (Khalkhali et.al. 2003, cited in Ohta, 2015). Hence, according to Rajan et. al. (2006, cited in Ohta ,2015) pointed out the fact that capital inflows in developing and emerging economies has not always contributed to increase GDP growth, and that those countries which are not dependent on external capital are likely to have higher growth.

\section{Capital Flow, Saving, Investment and Economic Growth: Nexus}

Ohta (2015) explained that domestic savings have not been effectively utilized for domestic investment in the real economy, but mobilized for other non-productive sectors of economies (e.g. financial sectors and real states) in both domestic and foreign markets. He also noted that although capital inflows had positive effect on the domestic growth.

According to findings of Admasu (2017) examined on the nexus of foreign capital inflows and economic growth in Ethiopia over the period 1981-2014 by using ARDL approach, explained the long run and short run effect of explanatory variables on the dependent variable. 
Thus, the result reveals that the flow of foreign aid has a negative effect on economic growth both in long run and short run. This is mainly because the existence of poor institutional arrangement and the funds are not always connected to the productive sectors. Similarly, the long run relationship between the flow of foreign direct investment and the economic growth is negative. The possible explanation for this negative effect is due to inadequate basic infrastructures and poor institutional quality in the country. However, the long run and short run effect of other foreign capital inflows and the short run effect of foreign direct investment are found to be insignificant in affecting real GDP per capita (Ibid).

\section{Methodology}

\section{Sources and Type of Data}

This study used annual time series (secondary) data ranging from 1980 to 2010 obtained from different publications of National Bank of Ethiopia (NBE), Ministry of Finance and Economic Development (MoFED), Statistical data base of Ethiopian Economic Association (EEA), African Development Indicator (ADI), IMF CD-ROM and WB CD-ROM.

\section{Description of Research Variables}

This study treated two types of variables which are dependent and independent (explanatory) variables. Hence, the study had one dependent variable, Real Gross Domestic Product (RGDP); and five different explanatory variables, Gross Domestic Saving (GDS), Gross Domestic Investment (GDI), Gross Capita Flow (GCF), Human Capital (HC) and Openness of Trade (OT).

\section{Model Specification:}

(I) Mathematical Model 
In line with the theoretical propositions reviewed in the literature, the impacts of capital flows on savings and investment implicitly, and on economic growth explicitly is examined by specifying equation.

\section{- Growth Function}

"The relationship between productivity growth and private capital flows appears to have strengthened over time. The productivity benefits of capital flows - through the transfer of technology and management techniques and the stimulation of financial sector development are significant in countries where a developed physical infrastructure, a strong business environment, and open trade regimes have facilitated the absorption of those flows, but not otherwise" [3]

Additionally, saving and investment have been considered as two macro-economic variables for achieving price stability and promoting employment opportunities thereby contributing to sustainable economic growth (Shimelis, 2014). Particularly, savings and economic growth have positive effect on each other in the long-run (R. Najarzadeh, et.al, 2014). According to Carroll and Weil, (1994) they established two interesting new empirical facts: First, at the aggregate level, periods of high income growth appear to be followed by periods of high saving. Second, among young households, those households who should expect faster income growth appear to save more than households who should expect slower income growth. Moreover, economic growth should be strengthened in order to achieve high level of domestic investment both in the short and long runs (Alfa and Garba, 2012).

Furthermore, the national return on domestic saving is approximately equal to the pretax domestic marginal product of capital since such saving does increase the domestic capital stock

\footnotetext{
$\overline{{ }^{[3]} \text { International Capital Flows and Economic Growth }}$
} 
rather than either flowing abroad or replacing foreign investment at home (Feldstein and Horioka, 2009).

Hence, RGDP is an increasing function of capital flows, gross domestic savings and gross domestic investment which can be given as below:

$$
\ln R G D P=f(\ln G C F, \ln G D S, \ln G D I)
$$

Furthermore, Equation (1) augmented by including two explanatory factors, human capital and openness international trade over the function of RGDP. Human capital is important sources of long -term growth because of its positive policies that enhance public and private investment in human capital, therefore, promote long-run economic growth (Lucas, 1988). According to Barro, (1991, cited in Shimelis, 2014), human capital plays a special role in a number of models of endogenous economic growth. Moreover, exchange rate and trade-openness per capita exhibited positive and significant impacts on GDP per capita (Yeboah et.al, 2012). In contrast, Ulaşan, (2012) does not support the proposition that openness has a direct robust relationship with economic growth in the long run. Hence, economic reforms in these areas should take priority over the policies enhancing trade openness (Ibid).

Accordingly, Equation (1) becomes as follows:

$$
\ln R G D P=f(\ln G C F, \ln G D S, \ln G D I, \ln H C, \ln O T)
$$

Where, RGDP is real gross domestic product, GCF is capital flow, GDI is Gross domestic investment, GDS is Gross Domestic saving, HC stands for human capital; and OT represents openness of trading.

\section{(II) Econometric Model}

The developed Econometric Model of Equation (2) is given as follows:

$$
\ln R G D P=\beta_{0}+\beta_{1} \ln G C F+\beta_{2} \ln G D S+\beta_{3} \ln G D I+\beta_{4} \ln H C+\beta_{5} \ln O T+\varepsilon_{i t}
$$


Where, $\beta_{0}$ is the intercept of dependent variable, RGDP; $\beta_{i},(i=1,2,3,4,5)$ is the $\mathrm{i}^{\text {th }}$ parameter associated with explanatory variables, GCF, FDI, GDS, HC, and OT, respectively; and $\varepsilon_{i t}$ is the white noise error term.

\section{Method of Data Analysis and Estimation Techniques}

\section{- Unit Root Test}

The first step in building dynamic econometric models entails a thorough investigation of the characteristics of the individual time series variables involved. When discussing stationary and non-stationary time series, the need to test for the presence of unit roots in order to avoid the problem of spurious regression should be stressed. Unit root test should be conducted in order to determine whether individual variables are stationary or not.

\section{- Co-integration Test: ARDL Bounds Testing Approach}

There are various techniques for conducting the Co-integration analysis among time-series variables. This paper adopts the so-called autoregressive distributed lag (ARDL) bounds which appear to be applied in recent empirical investigations.

As compared to other co-integration procedures, this method has certain econometric advantages. First, it is applicable irrespective of the degree of integration of the variables (i.e. whether the underlying variables are Purely $\mathrm{I}(0), \mathrm{I}(1)$ or mixture of both); and thus avoids the pre-testing of the order of integration of the variables. Second, the long-run and short-run parameters of the model are estimated simultaneously since it takes into account the error correction term in its lagged period. Third, the ARDL approach is more robust/strong/ and performs better for small sample sizes.

The ARDL approach requires estimating the conditional error correction version of the ARDL model for variables under estimation. Arising from the above, the augmented ARDL 
version of the model specified earlier is expressed as:

$$
\begin{gathered}
\Delta R G D P_{t}=\alpha_{0}+\sum_{i=0}^{p} \beta_{i} \Delta \ln R G D P_{t-i}+\sum_{i=0}^{q_{1}} \gamma_{i} \Delta \ln G C F+\sum_{i=0}^{q_{2}} \theta_{i} \Delta \ln G D S+\sum_{i=0}^{q_{3}} \pi_{i} \Delta \ln G D I+\sum_{i=0}^{q_{4}} \phi_{i} \Delta \ln H C+ \\
\sum_{i=0}^{q_{5}} \varphi \Delta \ln O T+\delta_{1} \ln G D P_{t-1}+\delta_{2} \ln G C F_{t-1}+\delta_{3} \ln G D S_{t-1}+\delta_{4} \ln G D I_{t-1}+\delta_{5} \ln H C_{t-1}+\delta_{6} \ln O T_{t-1}+\varepsilon_{i t}
\end{gathered}
$$

where, $\delta_{i}, \quad(i=1,2,3,4,5)$ - the parameters that the corresponding long-run multipliers, and $\beta_{i}, \gamma_{i}, \theta_{i}, \pi_{i}, \phi_{i}, \varphi_{i}$ are the short-run dynamic coefficients of the underlying ARDL model.

From Equation (4), we would first test the null hypothesis of no Co-integration, $H_{0}: \delta_{i}=0, i=1,2,3,4,5$ against the alternative using F-test with upper and lower critical values that are calculated automatically and reported after the ARDL regression estimates. Then finally, the order of the lag distribution function would be selected using one of the standard information criteria such as Akaike Information Criterion (AIC) and Schwartz-Bayesian Criterion (SBC). According to Pesaran and Shin (1995), (cited in Shimelis, 2014) argue that the SchwartzBayesian Criteria (SBC) is preferable to other model specification criteria because it often has more parsimonious/economical/ specifications. Therefore, a more parsimonious model is selected using the SBC criteria with the maximum lag order of two.

\section{- $\quad$ The Error Correction Models (ECM)}

Estimating a dynamic equation in the levels of the variables is problematic and differencing the variables is not a solution; so any information about the long run is removed. The more suitable approach is to convert the dynamic model into an error correction model (ECM). It is shown that this contains information on both the short-run and long-run properties of the model, with disequilibrium as a process of adjustment to the long-run model (Harris and Sollis, 2003, cited in Haile, 2015). The error correction (EC) representation of the ARDL model can be expressed as: 


$$
\begin{aligned}
\Delta \ln R G D P_{t}= & \alpha_{0}+\sum_{i=0}^{p} \beta_{i} \Delta \ln R G D P_{t-i}+\sum_{i=0}^{q_{1}} \gamma_{i} \Delta \ln G D S+\sum_{i=0}^{q_{2}} \theta_{i} \Delta \ln G D I+\sum_{i=0}^{q_{3}} \pi_{i} \Delta \ln H C \\
& +\sum_{i=0}^{q_{4}} \phi_{i} \Delta \ln O I T+\psi E C M_{t-1}
\end{aligned}
$$

where: $\psi$ is the speed of adjustment and $E C M_{t-1}$ is error correction term lagged by one period.

The existence of an error-correction term among a number of co-integrated variables implies that changes in the dependent variables are a function of both the level of disequilibrium in the Cointegration relation (expressed by the ECM) and the changes in other explanatory variables.

\section{- Granger Causality Test}

There are three approaches to implement the Granger causality test depending on time-series properties of variables; a VAR model in the level data (VARL), a VAR model in the firstdifferenced data (VARD), and a vector error correction model (VECM). The VECM approach which involves pre-testing through unit root and co-integration tests suffers from size distortions and can often lead to mistaken conclusions about causality. Hence, this study adopted the VAR approach. The lag augmented VAR representation of Equation (2) is given as below:

$$
\begin{aligned}
& \ln R G D P_{t}=\beta_{10}+\sum_{i=1}^{p} \theta_{1 i} \ln R G D P_{t-i}+\sum_{i=p+1}^{p+d_{\max }} \delta_{1 i} \ln R G D P_{t-i}+\sum_{i=1}^{p} \pi_{1 i} \ln G C F_{t-i}+\sum_{i=p+1}^{p+d_{\max }} \Omega_{1 i} \ln G C F_{t-1}+ \\
& \sum_{i=1}^{p} \lambda_{1 i} \ln G D S_{t-i}+\sum_{i=p+1}^{p+d_{\max }} \gamma_{1 i} \ln G D S_{t-i}+\sum_{i=!}^{p} \eta_{1 i} \ln G D I_{t-i}+\sum_{i=p+1}^{p+d_{\max }} \mu_{1 i} \ln G D I_{t-i}+\sum_{i=1}^{p} \phi_{1 i} \ln H C_{t-1}+ \\
& \sum_{i=p+1}^{p+d_{\max }} \varphi_{1 i} \ln H C_{t-1}+\sum_{i=1}^{p} \omega_{1 i} \ln O I T_{t-1}+\sum_{i=p+1}^{P+d_{\max }} \Psi_{1 i} \ln O I T_{t-1}+\varepsilon_{1 i} \\
& +\sum_{i=1}^{p} \omega_{2 i} \ln O I T_{t-1}+\sum_{i=p+1}^{P+d_{\max }} \Psi_{2 i} \ln O I T_{t-1}+\varepsilon_{2 t}
\end{aligned}
$$

$$
\begin{aligned}
& \ln G D S_{t}=\beta_{30}+\sum_{i=1}^{p} \theta_{3 i} \ln R G D P_{t-i}+\sum_{i=p+1}^{p+d_{\max }} \delta_{3 i} \ln R G D P_{t-i}+\sum_{i=1}^{p} \pi_{3 i} \ln G C F_{t-i}+\sum_{i=p+1}^{p+d_{\max }} \Omega_{3 i} \ln G C F_{t-1}+\sum_{i=1}^{p} \lambda_{3 i} \ln G D S_{t-i} \\
& +\sum_{i=p+1}^{p+d_{\max }} \gamma_{3 i} \ln G D S_{t-i}+\sum_{i=!}^{p} \eta_{3 i} \ln G D I_{t-i}+\sum_{i=p+1}^{p+d d_{\max }} \mu_{3 i} \ln G D I_{t-i}+\sum_{i=1}^{p} \phi_{3 i} \ln H C_{t-1}+\sum_{i=p+1}^{p+d \operatorname{dax}} \varphi_{3 i} \ln H C_{t-1} \\
& +\sum_{i=1}^{p} \omega_{3 i} \ln O I T_{t-1}+\sum_{i=p+1}^{P+d_{\max }} \Psi_{3 i} \ln O I T_{t-1}+\varepsilon_{3 i}
\end{aligned}
$$




$$
\begin{aligned}
& \ln G D S_{t}=\beta_{40}+\sum_{i=1}^{p} \theta_{4 i} \ln R G D P_{t-i}+\sum_{i=p+1}^{p+d i d_{\max }} \delta_{4 i} \ln R G D P_{t-i}+\sum_{i=1}^{p} \pi_{4 i} \ln G C F_{t-i}+\sum_{i=p+1}^{p+d d_{\max }} \Omega_{4 i} \ln G C F_{t-1}+\sum_{i=1}^{p} \lambda_{4 i} \ln G D S_{t-i} \\
& +\sum_{i=p+1}^{p+d_{\max }} \gamma_{4 i} \ln G D S_{t-i}+\sum_{i=!}^{p} \eta_{4 i} \ln G D I_{t-i}+\sum_{i=p+1}^{p+d_{\max }} \mu_{4 i} \ln G D I_{t-i}+\sum_{i=1}^{p} \phi_{4 i} \ln H C_{t-1}+\sum_{i=p+1}^{p+d_{\max }} \varphi_{4 i} \ln H C_{t-1} \\
& +\sum_{i=1}^{p} \omega_{4 i} \ln O I T_{t-1}+\sum_{i=p+1}^{P+d_{\max }} \Psi_{4 i} \ln O I T_{t-1}+\varepsilon_{4 t} \ldots \\
& \ln G D I_{t}=\beta_{50}+\sum_{i=1}^{p} \theta_{5 i} \ln R G D P_{t-i}+\sum_{i=p+1}^{p+d_{\max }} \delta_{5 i} \ln R G D P_{t-i}+\sum_{i=1}^{p} \pi_{5 i} \ln G C F_{t-i}+\sum_{i=p+1}^{p+d_{\max }} \Omega_{5 i} \ln G C F_{t-1}+\sum_{i=1}^{p} \lambda_{5 i} \ln G D S_{t-i} \\
& +\sum_{i=p+1}^{p+d_{\max }} \gamma_{5 i} \ln G D S_{t-i}+\sum_{i=!}^{p} \eta_{5 i} \ln G D I_{t-i}+\sum_{i=p+1}^{p+d_{\max }} \mu_{5 i} \ln G D I_{t-i}+\sum_{i=1}^{p} \phi_{5 i} \ln H C_{t-1}+\sum_{i=p+1}^{p+d_{\max }} \varphi_{5 i} \ln H C_{t-1} \\
& +\sum_{i=1}^{p} \omega_{5 i} \ln O T_{t-1}+\sum_{i=p+1}^{P+d_{\max }} \Psi_{5 i} \ln O I T_{t-1}+\varepsilon_{5 t} \\
& \ln G D I_{t}=\beta_{50}+\sum_{i=1}^{p} \theta_{5 i} \ln R G D P_{t-i}+\sum_{i=p+1}^{p+d d_{\max }} \delta_{5 i} \ln R G D P_{t-i}+\sum_{i=1}^{p} \pi_{5 i} \ln G C F_{t-i}+\sum_{i=p+1}^{p+d \max } \Omega_{5 i} \ln G C F_{t-1}+\sum_{i=1}^{p} \lambda_{5 i} \ln G D S_{t-i} \\
& +\sum_{i=p+1}^{p+d \max } \gamma_{5 i} \ln G D S_{t-i}+\sum_{i=!}^{p} \eta_{5 i} \ln G D I_{t-i}+\sum_{i=p+1}^{p+d d_{\max }} \mu_{5 i} \ln G D I_{t-i}+\sum_{i=1}^{p} \phi_{5 i} \ln H C_{t-1}+\sum_{i=p+1}^{p+d_{\max }} \varphi_{5 i} \ln H C_{t-1} \\
& +\sum_{i=1}^{p} \omega_{5 i} \ln O I T_{t-1}+\sum_{i=p+1}^{P+d_{\max }} \Psi_{5 i} \ln O I T_{t-1}+\varepsilon_{5 t} \\
& \ln H C_{t}=\beta_{60}+\sum_{i=1}^{p} \theta_{6 i} \ln R G D P_{t-i}+\sum_{i=p+1}^{p+d_{\max }} \delta_{6 i} \ln R G D P_{t-i}+\sum_{i=1}^{p} \pi_{6 i} \ln G C F_{t-i}+\sum_{i=p+1}^{p+d_{\max }} \Omega_{6 i} \ln G C F_{t-1}+\sum_{i=1}^{p} \lambda_{6 i} \ln G D S_{t-i} \\
& +\sum_{i=p+1}^{p+d_{\max }} \gamma_{6 i} \ln G D S_{t-i}+\sum_{i=1}^{p} \eta_{6 i} \ln G D I_{t-i}+\sum_{i=p+1}^{p+d d_{\max }} \mu_{6 i} \ln G D I_{t-i}+\sum_{i=1}^{p} \phi_{6 i} \ln H C_{t-1}+\sum_{i=p+1}^{p+d d_{\max }} \varphi_{6 i} \ln H C_{t-1} \\
& +\sum_{i=1}^{p} \omega_{6 i} \ln O I T_{t-1}+\sum_{i=p+1}^{P+d_{\max }} \Psi_{6 i} \ln O I T_{t-1}+\varepsilon_{6 t}
\end{aligned}
$$

where $\theta_{i} s, \delta_{i} s, \pi_{i} s, \Omega_{i} s, \lambda_{i} s, \gamma_{i} s, \eta_{i} s, \mu_{i} s, \phi_{i} s, \varphi_{i} s, \omega_{i} s, \Psi_{i} s$ are parameters of the model; $p$ is the true lag length; $\varepsilon_{i t}$ are the residuals of the model which represents in natural logarithm.

Equations (6) - (12) would be estimated to determine the direction of causality between the variables under consideration. From (6), Granger causality from $\ln G C F_{t}$ to $\ln R G D P_{t}$ implies $\pi_{11}=\pi_{12}=\ldots=\pi_{1 p} \neq 0 \quad ; \quad$ Granger causality from $\ln G D S_{t}$ to $\ln R G D P_{t}$ implies $\lambda_{11}=\lambda_{12}=\ldots=\lambda_{1 p} \neq 0 \quad ; \quad$ Granger causality from $\ln G D I_{t}$ to $\ln R G D P_{t}$ implies $\eta_{11}=\eta_{12}=\ldots=\eta_{1 p} \neq 0$. From (7), Granger causality from $\ln R G D P_{t}$ to $\ln G C F_{t}$ implies $\theta_{21}=\theta_{22}=\ldots=\theta_{2 p} \neq 0 ;$ Granger causality from $\ln G D S_{t}$ to $\ln C F_{t}$ implies $\lambda_{21}=\lambda_{22}=\ldots=\lambda_{2 p} \neq 0$ ; Granger causality from $\ln G D I_{t}$ to $\ln G C F_{t}$ implies $\eta_{21}=\eta_{22}=\ldots=\eta_{2 p} \neq 0$. From (8), Granger 
causality from $\ln R G D P_{t}$ to $\ln G D S_{t}$ implies $\theta_{31}=\theta_{32}=\ldots=\theta_{3 p} \neq 0$; Granger causality from $\ln G C F_{t}$ to $\ln G D S_{t}$ implies $\pi_{31}=\pi_{32}=\ldots=\pi_{3 p} \neq 0$; Granger causality from $\ln G D I_{t}$ to $\ln G D S_{t}$ implies $\eta_{31}=\eta_{32}=\ldots=\eta_{3 p} \neq 0$. From (9), Granger causality from $\ln R G D P_{t}$ to $\ln G D I_{t}$ implies $\theta_{41}=\theta_{42}=\ldots=\theta_{4 p} \neq 0$; Granger causality from $\ln C F_{t}$ to $\ln G D I_{t}$ implies $\pi_{41}=\pi_{42}=\ldots=\pi_{4 p} \neq 0 ;$ Granger causality from $\ln G D S_{t}$ to $\ln G D I_{t}$ implies $\eta_{41}=\eta_{42}=\ldots=\eta_{4 p} \neq 0$. Then, Granger causality is tested using the modified Wald (MWald) test which is theoretically very simple, as it involves estimation of a VAR model augmented in a straight forward way.

\section{- Impulse Response Function (IRF)}

In empirical research, it is often necessary to know the response of one variable to an impulse in another variable in a system that involves a number of further variables as well. Thus, one would like to investigate the impulse response relationship between two variables in a higher dimensional system (Lutkepohl, 2005). To this end, generalized impulse response which is invariant to the ordering of the variables in the VAR has been used

\section{Estimation and Discussions of Results}

\section{- Descriptive Statistics}

Before directly going to the econometric estimation, it is better to have a look at the descriptive statistics of the variables under consideration. This is vital because these statistics summarize the statistical properties of the series in the model such that some explanations about the behavior of the series can be offered at a glance (Table 4.1).

\section{- Unit Root Testing}

The null hypothesis for the test in ADF depicts that the data series under consideration has unit root while the alternative hypothesis claims that the series is stationary. As can be seen from 
Table 4.2, ADF test witnessed that RGDP in natural log at level is non-stationary since we cannot reject the null hypothesis of unit root at $1 \%, 5 \%$, and $10 \%$ level of significance.

Table 4.1: Descriptive Statistics of variables in the model (STATA/SE 12 output)

\begin{tabular}{lcccccc}
\hline Statistics & InRGDP & InGCF & InGDS & InGDI & InHC & InOT \\
\hline Mean & 11.0652 & 8.9304 & 8.2093 & 2.1780 & 2.0972 & 1.8216 \\
Median & 10.9885 & 8.7647 & 8.2121 & 2.1707 & 2.1056 & 1.8399 \\
Maximum & 12.0414 & 11.7789 & 10.714 & 2.4663 & 2.3716 & 2.0687 \\
Minimum & 10.5044 & 7.22023 & 6.2982 & 1.9767 & 1.8403 & 1.5781 \\
Std. Dev. & 0.42322 & 1.39209 & 1.0682 & 0.1530 & 0.1290 & 0.1253 \\
Skewness & 0.85051 & 0.45506 & 0.3776 & 0.2831 & 0.1205 & 0.0816 \\
Kurtosis & 2.66122 & 2.01514 & 2.5295 & 1.8138 & 2.3518 & 2.1051 \\
Sum & 343.0211 & 276.8414 & 254.4884 & 67.51786 & 65.0126 & 6.4695 \\
Observations & 30 & 30 & 30 & 30 & 30 & 30 \\
\hline
\end{tabular}

On the other hand, when the first difference of natural log of RGDP is considered it becomes stationary at $1 \%, 5 \%$ and $10 \%$ level of significances. Coming to the ADF test, the result reveals that the first difference of $\operatorname{lnRGDP}$ is stationary at $1 \%, 5 \%$ and $10 \%$ level of significance. However, lnRGDP at level is not stationary. The ADF test shows that none of the variable is stationary at level. However, taking the first difference of the variables makes them stationary since the null hypothesis of unit root is rejected at $1 \%, 5 \%$ and $10 \%$ level of significance.

Table 4.2: Result for the ADF-Unit Root Test (STATA/SE 12 Output)

\begin{tabular}{|c|c|c|c|c|c|c|}
\hline \multicolumn{7}{|c|}{ Variables at the level } \\
\hline Variables & Test Statistics & $1 \% \mathrm{CV}$ & $5 \% \mathrm{CV}$ & $10 \% \mathrm{CV}$ & P-Value & Decision \\
\hline $\operatorname{lnOT}$ & -0.983 & -3.723 & -2.989 & -2.625 & 0.7595 & \\
\hline $\ln \mathrm{HC}$ & -0.827 & -3.723 & -2.989 & -2.625 & 0.8112 & \\
\hline $\operatorname{lnGDI}$ & 0.648 & -3.723 & -2.989 & -2.625 & 0.9887 & \\
\hline $\operatorname{lnGDS}$ & -0.494 & -3.723 & -2.989 & -2.625 & 0.8931 & \\
\hline $\operatorname{lnGCF}$ & 1.441 & -3.723 & -2.989 & -2.625 & 0.9973 & \\
\hline $\operatorname{lnRGDP}$ & 2.285 & -3.723 & -2.989 & -2.625 & 0.9989 & \\
\hline \multicolumn{7}{|c|}{ Variables at the first difference } \\
\hline dflnOT & -5.058 & -3.723 & -2.989 & -2.625 & $0.0000 * * *$ & $\mathrm{I}(1)$ \\
\hline dflnHC & -7.966 & -3.723 & -2.989 & -2.625 & $0.0000 * * *$ & $\mathrm{I}(1)$ \\
\hline dflnGDI & -6.250 & -3.723 & -2.989 & -2.625 & $0.0000 * * *$ & $\mathrm{I}(1)$ \\
\hline dflnGDS & -7.765 & -3.723 & -2.989 & -2.625 & $0.0000 * * *$ & $\mathrm{I}(1)$ \\
\hline dflnGCF & -6.250 & -3.723 & -2.989 & -2.625 & $0.0000 * * *$ & $\mathrm{I}(1)$ \\
\hline dflnRGDP & -4.378 & -3.723 & -2.989 & -2.625 & $0.0003 * * *$ & $\mathrm{I}(1)$ \\
\hline
\end{tabular}

In general, the ADF test from Table 4.2 shows that all variables are integrated of orders one, I (1). That is, all variables are stationary at their first difference. Thus, the determination of co- 
integration relationships using the ARDL technique does not face a problem from the existence of I(2) or beyond variables in the model specified.

\section{- Co-integration Test and Estimation of Long-run Relationship}

A two-step procedure is used in estimating the long-run relationship: an initial examination of the existence of a long-run relationship among the variables in Equation (2) is followed by an estimation of the short-run and long-run parameters.

\section{- Bound Test}

The results in Table 4.3 show that $\operatorname{lnRGDP}$, lnGCF, lnGDS, lnGDI, lnHC and lnOT are cointegrated when $\operatorname{lnRGDP}$ is taken as dependent variable without intercept (i.e. constant $=0$ ) since F-statistic, also written as FlnRGDP $(\operatorname{lnRGDP} \mid \operatorname{lnGCF}$, $\operatorname{lnGDS}$, $\operatorname{lnGDI}$, $\operatorname{lnHC}$, lnOT) $=4.7154$ [with lag order of $(1,0,0,0,0)$ selected by the SBC] is greater than both lower and upper bounds at $95 \%$ critical values of Narayan (2004) and Pesaran et.al. (2001) which is 2.5080 and 3.9478, respectively. However, while we include (consider) the intercept (i.e. constant $\neq 0$ ) in the model, the result shows that variables are not co-integration because F-statistics value, 2.5821 less than both the $95 \%$ Upper Bound critical values between the bounds (lower and upper) which are 3.1815 and 4.5996 , respectively. Hence, we take the model without intercept to test the cointegration. Thus, the existence of a clear co-integrating equation according to Pesaran et.al. (2001) indicates that there is a long- run relationships among the variables under consideration.

Before estimating the long-run relationship and the short-run dynamics of the model, it is important to analyze performance of the ARDL estimates through the diagnostic tests. As can be seen from the result, R- squared is 99 percent and it is statistically significant (with P-value $=$ 0.000 ) at $1 \%$ level of significance implying that the model fits well. Moreover, the model (ARDL estimates) is free from the problem of serial correlation, functional form, 
heteroskedasticity and normality as revealed in LM and F version of tests because we cannot reject the null hypothesis of each test statistic (See on appendix-I).

Table 4.3: Estimated Long Run Coefficients using the ARDL Approach (Output obtained from Microfit 5.5 version)

\begin{tabular}{|c|c|c|c|c|}
\hline \multicolumn{5}{|c|}{$\begin{array}{l}\text { Estimated Long Run Coefficients using the ARDL Approach } \\
\text { ARDL }(0,0,1,0,1,1) \text { selected based on Schwarz Bayesian Criterion }\end{array}$} \\
\hline \multicolumn{5}{|c|}{ Dependent Variable in InRGDP } \\
\hline Regressor & Coefficient & Standard & Error & T-Ratio[Prob] \\
\hline $\operatorname{lnGCF}$ & 3.2651 & 1.6328 & & $1.9997[0.057]^{*}$ \\
\hline $\operatorname{lnGDS}$ & -3.4458 & 1.7935 & & $-1.9212[0.067]^{*}$ \\
\hline $\operatorname{lnGDI}$ & -26.5916 & 14.7476 & & $-1.8031[0.084]^{*}$ \\
\hline $\ln \mathrm{HC}$ & 31.0953 & 15.2222 & & $2.0428[0.052]^{*}$ \\
\hline $\operatorname{lnOT}$ & 1.7171 & 0.91013 & & $1.8866[0.071]^{*}$ \\
\hline R-Squared & 0.98981 & R-Bar-S & uared & 0.98768 \\
\hline S.E of Reg. & 0.04690 & F-Stat. I & $(5,24)$ & $466.1148[0.000$ \\
\hline \multicolumn{5}{|c|}{ Diagnostic Test } \\
\hline \multicolumn{5}{|c|}{ LM Version } \\
\hline A: Serial Correlation & \multicolumn{2}{|c|}{$\operatorname{CHSQ}(1)=0.38599[0.534]$} & \multicolumn{2}{|c|}{$\mathrm{F}(1,22)=0.28675[0.598]$} \\
\hline B: Functional Form & \multicolumn{2}{|c|}{$\operatorname{CHSQ}(1)=0.38084[0.537]$} & \multicolumn{2}{|c|}{$\mathrm{F}(1,22)=0.28287[0.600]$} \\
\hline C: Normality & \multicolumn{2}{|c|}{$\mathrm{CHSQ}(2)=1.0562[0.590]$} & \multicolumn{2}{|c|}{ Not applicable } \\
\hline D: Heteroscedasticity & \multicolumn{2}{|c|}{$\operatorname{CHSQ}(1)=3.8315[0.050]$} & \multicolumn{2}{|c|}{$F(1,28)=4.0996[0.053]$} \\
\hline
\end{tabular}

Table 4.3 presents the estimated coefficients of the long-run relationship along with the diagnostic tests of the model. Based on the results, the long-run growth equation is given as :

$$
\begin{aligned}
& \ln R G D P=3.2651 \ln G C F-3.4458 \ln G D S-26.5916 \ln G D I+31.0953 \ln H C+1.7171 \ln O T \\
& P \text {-value } \quad(0.057)
\end{aligned}
$$

The estimated coefficients show that gross capital flow, human capital and openness of trading have a statistically significant positive impact on economic growth, which is in line with theoretical argument that capital flow, human capital and openness positively contributes to economic growth. More specifically, the elasticity of capital flow indicated that a $10 \%$ increase in capital flow leads to $4.265 \%$ increase in economic growth on average, keeping other variables constant. Similarly, the long-run elasticity of human capital is 31.0953 and openness of trading is 
0.071 which imply that a $10 \%$ rise in human capital and openness of trading result in about 31.0953 and 0.071 percent increase in economic growth, respectively.

However, as seen Table 4.3, the long-run model suggests that gross domestic saving and gross domestic investment have significantly negative effect on economic growth. Particularly tabulation reveals that, the long-run elasticity of gross domestic saving is -0.067 and gross domestic investment is -0.084 which imply that a $10 \%$ fall in gross domestic saving and gross domestic investment result in about 0.067 and 0.084 percent decrease in economic growth, respectively .

\section{- The Short Run Dynamic Modeling: (Error Correction Model)}

After estimating the long-run coefficients, we obtain the error correction representation (see Equation 5) of the ARDL model. The result of the short-run dynamic growth model is presented in Table 4.4. About 72 percent of the variation growth is explained by explanatory variables included in the model. R-squared which is 72.02 is statistically significant at $1 \%$ level of significance implying that the model fits well since the explanatory variables are jointly significant at $1 \%$ level of significance.

The coefficient on the lagged error-correction term is highly significant at one percent level of significance with the expected sign, which confirms the result of the bounds test for cointegration. The estimated coefficient of the $\mathrm{ECM}_{\mathrm{t}-1}$ is equal to 0.17 which states that departure (disequilibria) from the long-term growth path due to a certain shock is adjusted (converge back to long-run equilibrium) by 17 percent over the next year, significant at the $1 \%$ level of significance.

Based on Table 4.4, the short-run dynamics of growth equation is given as:

$\begin{array}{llllll}\Delta \ln R G D P=0.55738 \Delta \operatorname{lnGCF}-0.58823 \Delta \operatorname{lnGDS} & -4.5395 \Delta \operatorname{lnGDI}+5.3083 \Delta \ln H C+0.2931 \Delta \operatorname{lnOT}+0.1707 \mathrm{ECM}_{\mathrm{t}-\mathrm{C}} \\ \mathrm{P} \text { - value } & (0.010) & (0.026) & (0.019) & (0.014) & (0.047)\end{array}$


Table 4.4: Short Run Dynamics Result for the Selected ARDL Model

Error Correction Representation for the Selected ARDL Model

(ARDL $(1,0,0,0,0,0)$ selected based on Schwarz Bayesian Criterion)

\begin{tabular}{cccc}
\hline \multicolumn{4}{c}{ Dependent Variable is $\Delta \ln R G D P$} \\
\hline Regressor & Coefficient & Standard Error & T-Ratio[Prob] \\
$\Delta \ln G C F$ & 0.55738 & 0.19936 & $2.7958[0.010]^{* *}$ \\
$\Delta \ln G D S$ & -0.58823 & 0.24737 & $-2.3779[0.026]^{* *}$ \\
$\Delta \ln G D I$ & -4.5395 & 1.8002 & $-2.5217[0.019]^{* *}$ \\
$\Delta \ln H C$ & 5.3083 & 1.9962 & $2.6592[0.014]^{* *}$ \\
$\Delta \ln O T$ & 0.29312 & 0.13992 & $2.0949[0.047]^{* *}$ \\
ECMt-1 & -0.17071 & 0.057872 & $-2.9498[0.007]^{* * *}$ \\
R-Squared & 0.64662 & R-Bar-Squared & 0.57300 \\
S.E. of Reg. & 0.046905 & F-Stat. F $(5,24)$ & $8.7832[0.000]$ \\
\hline
\end{tabular}

Notes: Figures in parenthesis are p-values. $\Delta$ represents the first difference. ***, ** and * means the coefficients are significant at $1 \%, 5 \%$ and $10 \%$ level of significance respectively.

From this equation, the result reveals that the estimated coefficients of $\ln \mathrm{GCF}, \ln \mathrm{HC}$ and $\operatorname{lnOT}$ are statistically significant with the positive sign. In line with the postulates of growth theories; gross capital flow, returns to schooling (human capital) and trade openness have a positive effect on real gross domestic product of Ethiopia in the short-run. Even though gross domestic savings (lnGDS) and human gross domestic investment (lnGDI) are statistically significant, they have a negative effect on the real economic growth of Ethiopia in the short-run. Particularly, since (gross) capital flow and real gross domestic product have positive relationship, the one percentage change in percentage of GDF to RGDP ratio causes RGDP to be changed approximately by $56 \%$, other variables remaining constant.

\section{- Stability Test}

The stability of the long-run coefficient is tested by the short-run dynamics. Once the Error correction model has been estimated the cumulative sum of recursive residuals (CUSUM) and the CUSUM of square (CUSUMSQ) is applied to assess the parameter stability (Pesaran, 1997). Plots of CUSUM and CUSUMSQ of the growth equation in its SR version are drown. (See on Appendix-III). 


\section{- Granger Causality Test}

As can be seen from Table 5, the optimal lag length is one. Since all variables become stationary after the first differencing, it implies that dmax is also one. We then estimate a system of VAR in levels with a total of $\left(\mathrm{d}_{\max }+\mathrm{k}=1+1\right)$ which is 2 lags; where $\mathrm{k}$ is the lag length selected by information criteria. Using this information, the system of equations (i.e. Equations 6 -12) is jointly estimated as a "Seemingly Unrelated Regression Equations" (SURE) model.

\section{Table 4.5: Estimates of long-run Granger Causality Wald Tests}

\begin{tabular}{|c|c|c|c|}
\hline Equation & Excluded & $\chi^{2}$ & Prob. $>\chi^{2}$ \\
\hline $\ln \mathrm{RGDP}$ & $\operatorname{lnGCF}$ & 3.9538 & 0.138 \\
\hline $\ln \mathrm{GCF}$ & $\ln \mathrm{RGDP}$ & 0.02683 & 0.987 \\
\hline
\end{tabular}

Table 4.5 shows that the null hypothesis that 'Granger no-causality from (gross) cash flow to economic growth' can be rejected since the causality is insignificant even at $10 \%$ level of significance. Hence, the alternative hypothesis that 'Granger causality from gross capital flow to economic growth' is accepted. That is, gross capital flow causes positively the economic growth with magnitude (scalar) of 3.9538. Similarly, when we check the reverse effect of economic growth on gross capital flow, it causes by amount of scalar 0.02683 positively. Therefore, the result reveals that the Granger causality between gross capital flow and economic growth is bidirectional effect. That is, gross capital flow Granger causes economic growth and there is a feedback from economic growth. But, the effect of the reverse cause (i.e. from economic growth to gross capital flow) is weaker than the effect of exogenous variable on the endogenous variable (i.e. from gross capital flow to economic growth).

\section{- Impulse Response Functions (IRF)}

The impulse response functions of variable lnRGDP and lnGCF for eight years is estimated generalized Table 4.6 and illustrates graphically in Fig. 4.1 (seen on Appendix-IV). While we consider Impulse (lnGCF) and Response (lnRGDP) that a one standard deviation disturbance 
originating from economic growth results in an approximately 4.76 percent increase in gross capital flow in the first period. Similarly, it continuously increases to about 24.7 percent in the third period and starts increasing after the fifth period and reaches about 33.5 percent in the $8^{\text {th }}$ period implying that the impact of gross capital flow on economic growth is positively increased in both short-run and long-run. Thus, the impulse of domestic cash flow on the economic growth is increasing response.

Table 4.6: Generalized Impulse Responses to one SE shock in the equation for InRGDP IRF(varbasic), Impulse (InGCF), Response (InRGDP)

\begin{tabular}{cc}
\hline Horizon & IRF \\
\cline { 2 - 2 } $\mathbf{0}$ & 0.000000 \\
$\mathbf{1}$ & 0.047602 \\
$\mathbf{3}$ & 0.116382 \\
$\mathbf{4}$ & 0.166032 \\
$\mathbf{5}$ & 0.210189 \\
$\mathbf{6}$ & 0.277131 \\
$\mathbf{7}$ & 0.308682 \\
$\mathbf{8}$ & 0.335229 \\
\hline IRF(varbasic), Impulse (InGCF), Response (lnRGDP) \\
\hline Horizon & IRF \\
\hline 0 & 0.000000 \\
1 & 0.094813 \\
2 & 0.038955 \\
3 & 0.031539 \\
4 & 0.013343 \\
5 & 0.002886 \\
6 & -0.006844 \\
7 & -0.014321 \\
8 & -0.02063 \\
\hline
\end{tabular}

However, when we see in reverse direction by considering Impulse (lnRGDP) and Response $(\mathrm{lnGCF})$ that a one standard deviation disturbance originating from economic growth results in an approximately 9.48 percent increase in gross capital flow in the first period. But it continuously declines to about 0.29 percent in the fifth period and starts negatively decreasing after the fifth period and reaches about 2.06 percent in the $8^{\text {th }}$ period implying that the impact of economic growth on gross cash flow causes positively decreased for short-run and 
negatively decreased for long-run. Thus, the impulse of economic growth on the domestic cash flow is a decreasing response.

\section{Conclusion and Policy Implications}

\section{- Conclusion}

We attempts to offer evidence on the relationship among the natural logarithm of real gross domestic product (lnRGDP), gross capital flow (lnGCF), gross domestic saving (lnGDS), gross domestic investment (lnGDI) and openness of trade (lnOT) in Ethiopia. The series used in the analysis was tested for stationarity, using Augmented Dickey-Fuller (ADF) . The result indicted that the variables are not stationary at level, though stationary at first difference. On the Johansen Cointegration test, it shows the presence of long-run relationship among the cointegrating variables. Furthermore, an Engle-Granger 2-Step procedure was applied and an error correction model (ECM) was developed from long-run static model. The error correction term in the shortrun dynamic model has a statistically significant coefficient with the appropriate negative sign and this is a requirement for dynamic stability of the model.

As determinants of growth, the long-run coefficients of the natural logarithm of gross capital flow, human capital and openness of trading are positive and statistically significant at $10 \%$ percent level of significance, implying that these three variables have a significant and positive impact on growth in the long-run. However, the long-run coefficients of gross domestic saving and gross domestic investment are significantly negative effect on economic growth.

Similarly, ARDL based short-run dynamic modeling (Error Correction Model) for growth shows that gross capital flow, human capital, and trade openness have statistically significant positive effect on growth in the short-run. Furthermore, the stability of the estimated parameters of both short-run and long-run relationships is supported by CUSUM and CUSUMSQ stability tests. 
The direction of causal relationship among the gross capital flow and economic growth using the Granger causality tests suggests that the direction of Granger causality from gross capital flow to economic growth which is in line with the conventional wisdom. That is, gross capital flow causes positively the economic growth. In turn, even though the Granger reverse causality from economic growth to gross capital flow is weaker, it a positive cause. Therefore, the result reveals that the Granger causality between gross capital flow and economic growth is bi-directional effect. That is, gross capital flow Granger causes economic growth and there is a feedback from economic growth.

However, Granger causality running from gross capital flow to economic growth is the stronger and positively increased as suggested by impulse response and variance decompositions in both short-and long-run. But, Granger causality running from economic growth to gross capital flow is weaker and negatively decreased in long-run, even though positively decreased in short-run.

\section{- Policy Implication}

Empirical evidences show that the capital flows of a country can be either positive or negative based on their import and export levels, economic and political stability, and financial markets. Strong capital flows into a country can result in many benefits. As firms and people invest new capital from outside countries, this can lead to new factories, research and development advances, and technology improvements. Ultimately, this results in more jobs, increased income, lower prices, and higher standards of living for citizens. One risk of too much capital inflow is that inflation could result if a country is already operating at full capacity and continues to receive strong foreign investment.

Furthermore, capital flows are very important because of their potential effects on the macroeconomic stability, monetary and exchange rate management as well as competitiveness of 
the export and external sectors viability of a country. This is because no matter the nature of capital flows (flows over a medium-to long-term), they are expected to influence the monetary aggregates, especially, the economy's net foreign assets (NFA), inflation as well as real effective exchange rate, aggregate output (GDP) and possibly the domestic interest rates.

Consequently, any policy recommendation on this should understand, the nature, what drives the capital flows and the impact of its sudden surge or reversal on economy. It is recommended that government should continue to pursue trade and foreign exchange policies that would ensure competitiveness of the export sector viability and economic growth, while foreign direct investment should be encouraged amidst thriving business environment that would engender economic growth.

\section{- Reference}

Admasu Abera, (2017). The Nexus of Foreign Capital Inflows and Economic Growth in Ethiopia. Mendel University in Brno Faculty of Business and Economics

Bülent Ulaşan, (2012). Openness to International Trade and Economic Growth: A Cross-Country Empirical Investigation. Central Bank of the Republic of Turkey

Carroll, C. D. and Weil, D. N., (1994). Saving and Growth: A Reinterpretation. Carnegie-Rochester Conference series on Public policy 40 (1994) 133-192; North-Holland

Haile Girma, (2015). The impact of foreign aid on economic growth: Empirical evidence from Ethiopia (1974-2011) using ARDL approach. Journal of Research in Economics and International Finance (JREIF), Vol. 4(1)

Hanan Farag Mohamed, (N.D). The Impact of Foreign Capital Inflows on Economic Growth and Employment in Egypt: A Sectorial Empirical Analysis.

Hideaki OHTA, (2015). The Effects of International Capital Flows on Domestic Savings, Investment and Growth: Facts on 'F-H Puzzle' in OECD and Emerging Economies. The International Studies Association of Ritsumeikan University: Ritsumeikan Annual Review of International Studies, 2015. Vol.14

Ibrahim Alley, (2017). Capital flow surges and economic growth in sub-Saharan Africa: Any role for capital controls?

Lucas Jr., R. E. (1988). On the mechanics of economic development. Journal of Monetary Economics, 22(1), 3-42.

Musibau H. O., Mahmood S., Hammed A. Y., (2017). The Impact of Foreign Capital Inflows, Infrastructure and Role of Institutions on Economic Growth: An Error Correction Model. Academic Journal of Economic Studies Vol. 3.

Najarzadeh, R., Reed M. \& Tasan M. , (2014). Relationship between Savings and Economic Growth: The Case for Iran. Journal of International Business and Economics; December 2014, Vol. 2, No. 4

Shimelis, K. H. (2014), Savings, Investment and Economic Growth in Ethiopia: Evidence from ARDL approach to cointegration and TYDL granger causality tests. Journal of Economics and International Finance, 6(10).

Tasew Tadesse, (2011). Foreign aid and economic growth in Ethiopia. Dilla University; https://mpra.ub.unimuenchen.de/33953/ Wondwesen, W. (2011). The Impact of Foreign Capital Inflows on Economic Growth, Savings and Investment in Ethiopia. Unpublished M.Sc. Thesis, Addis Ababa University.

Yeboah O., Naanwaab C., and Saleem S., (2012). Effects of Trade Openness on Economic Growth: The Case of African Countries. Agribusiness, Applied Economics and Agriscience Education-NCA\&T; Birmingham

\section{Websites:}

- $\quad$ http://www.businessdictionary.com

- $\quad$ https://www.investopedia.com 


\section{- Appendices}

* Appendix-I: Results of Bounds Test for Cointegration

\begin{tabular}{|c|c|c|c|}
\hline $\begin{array}{l}\text { Dependent Variables } \\
\text { (Excluding Intercepts) }\end{array}$ & F-Statistics & Decision & \\
\hline $\mathrm{F}_{\operatorname{lnRGDP}}(\operatorname{lnRGDP} \mid \operatorname{lnGCF}, \operatorname{lnGDS}, \operatorname{lnGDI}, \ln H C, \operatorname{lnOT})$ & $(1,0,0,0,0,0)$ & $4.7154^{*}$ & Cointegrated \\
\hline $\mathrm{F}_{\operatorname{lnGCF}}(\operatorname{lnGCF} \mid \operatorname{lnRGDP}, \operatorname{lnGDS}, \operatorname{lnGDI}, \ln \mathrm{HC}, \operatorname{lnOT})$ & $(1,0,1,0,0,1)$ & $16.8935^{*}$ & Cointegrated \\
\hline $\mathrm{F}_{\operatorname{lnGDS}}(\operatorname{lnGDS} \mid \operatorname{lnGCF}, \operatorname{lnRGDP}, \operatorname{lnGDI}, \ln \mathrm{HC}, \operatorname{lnOT})$ & $(0,0,0,1,0,0)$ & --- & \\
\hline $\mathrm{F}_{\operatorname{lnGDI}}(\operatorname{lnGDI} \mid \operatorname{lnGCF}, \operatorname{lnGDS}, \ln \mathrm{RGDP}, \ln \mathrm{HC}, \operatorname{lnOT})$ & $(1,1,0,0,0,0)$ & $14.2454^{*}$ & Cointegrated \\
\hline $\mathrm{F}_{\operatorname{lnHC}}(\operatorname{lnHC} \mid, \operatorname{lnGCF}, \operatorname{lnGDS}, \operatorname{lnGDI}, \operatorname{lnRGDP}, \operatorname{lnOT})$ & $(0,0,0,1,0,0)$ & ---- & \\
\hline $\mathrm{F}_{\operatorname{lnOT}}(\operatorname{lnOT} \mid, \operatorname{lnGCF}, \operatorname{lnGDS}, \operatorname{lnGDI}, \ln \mathrm{HC}, \ln \mathrm{RGDP})$ & $(1,0,0,0,0,0)$ & 2.6000 & Non-integrated \\
\hline
\end{tabular}

Note: * means F-statistics is greater than the $95 \%$ Upper Bound critical value.

\section{* Appendix- II: Results of ARDL Estimated and Diagnostic Tests; and Results of Authogresive Distributed Lag} Estimates

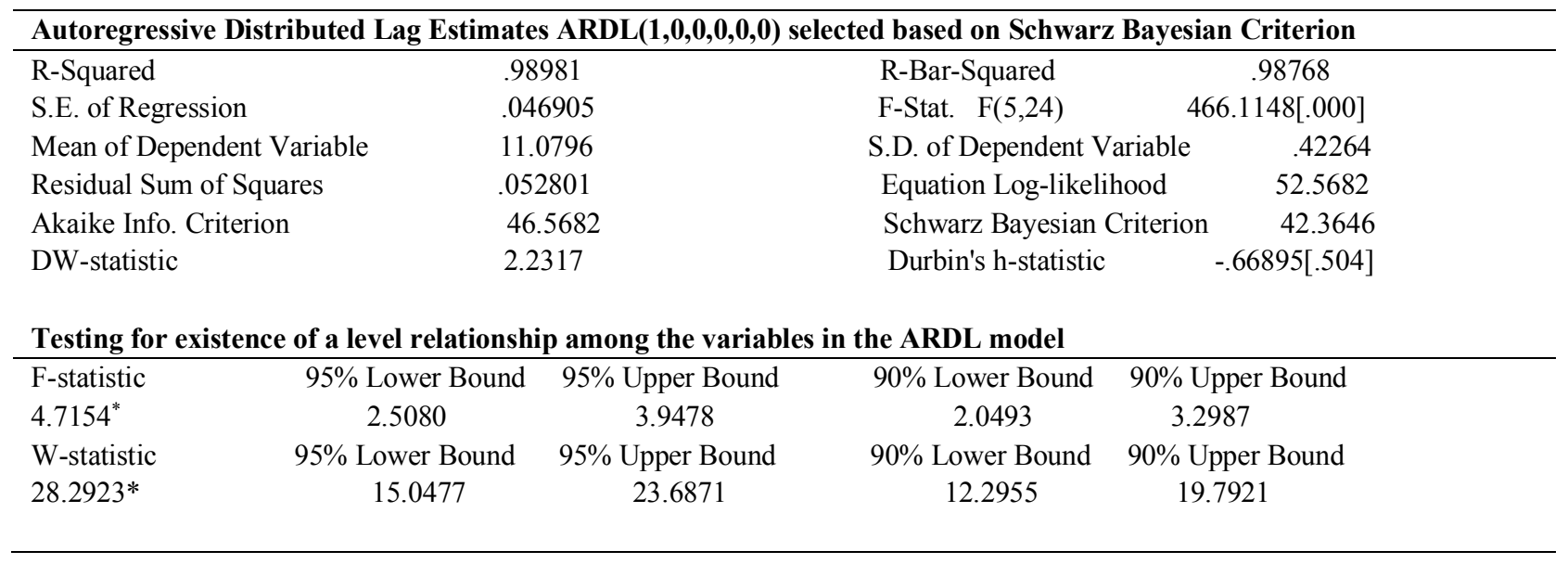

Note: * means F-statistics is greater than the 95\% Upper Bound critical value. Dependent variable is LNRGDP 30 observations used for estimation from 1981 to 2010 


\section{* Appendix -III: Stability Test}

Plot of Cumulative Sum of Recursive Residuals

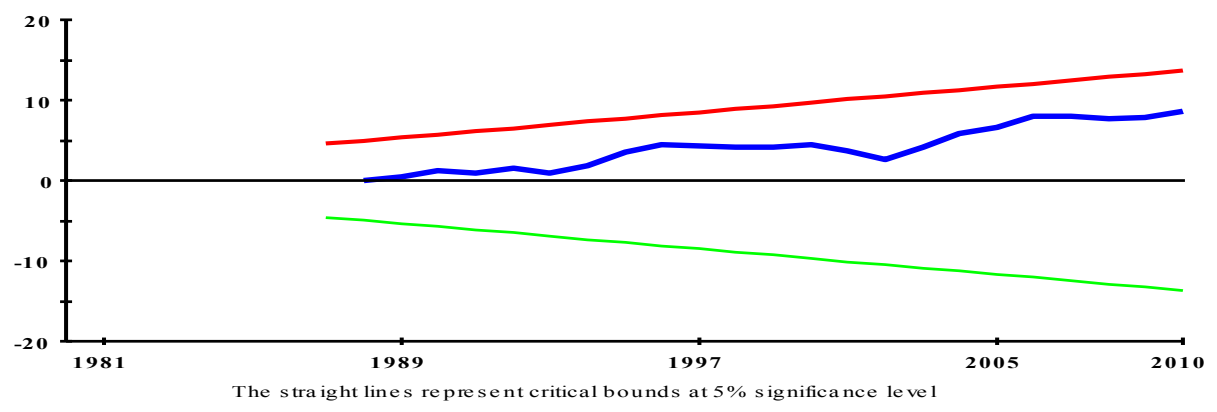

Plot of Cumulative Sum of Squares of Recursive Residuals

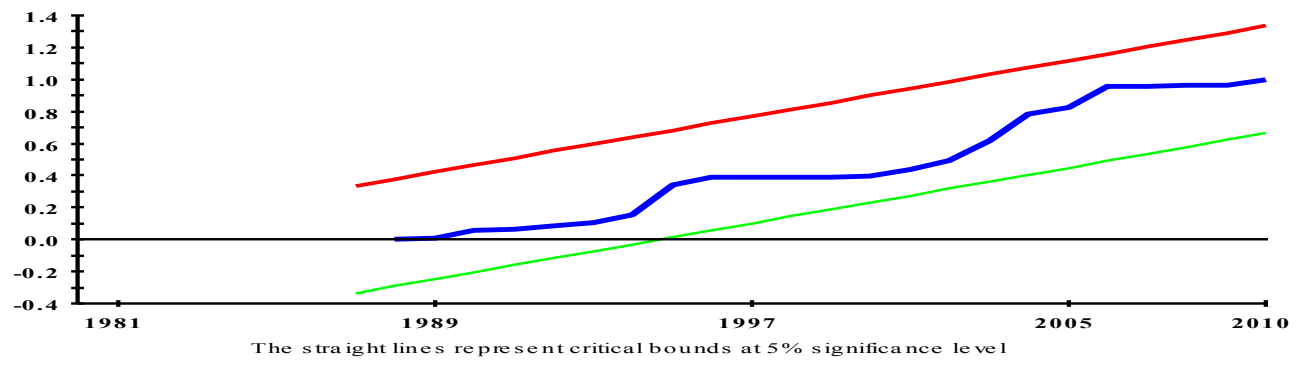

* Appendix-IV: Impulse-Response Function (IRF): InRGDP vs InGCF

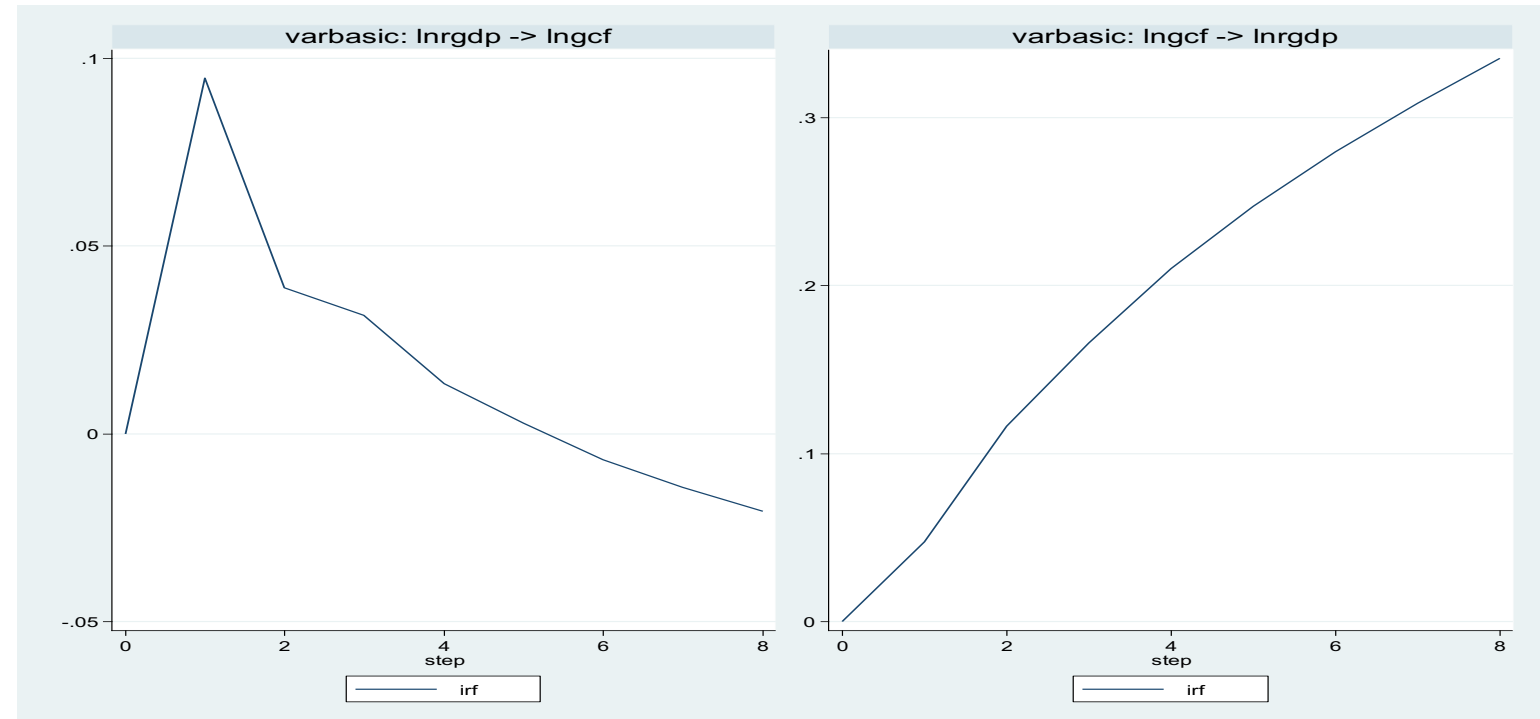

Figure 4.1 